\title{
HUBUNGAN MINUM OBAT ANTI HIPERTENSI DENGAN MELAKUKAN KONTROL TEKANAN DARAH RUTIN PADA LANSIA
}

\author{
RADEN SITI MARYAM, TIEN HARTINI, ROSIDAWATI* \\ * Dosen Jurusan Keperawatan Poltekkes Kemenkes Jakarta III
}

\begin{abstract}
Introduction: Hypertension is a disease characterized by above-normal blood pressure, usually does not cause symptom, it is often called the silent killer. An estimated $76 \%$ cases of hypertension in people who have not been diagnosed, in this case a person does not know that he was suffering from hypertension. This study aimed to get an overview of the factors that affect blood pressure control in the elderly. Methods: The study was a non - experimental (observational) with cross-sectional approach. The population in this study were all elderly people who come on Posyandu Lansia in Puskesmas Pulogadung district, East Jakarta with sample of 46 respondents. Results and Discussion: There was a significant relationship between taking antihypertensive medication ; have a history of hypertension; and long suffered from hypertension with blood pressure control routine ( $p=0.004 ; p=0.018 ; p=0.026$ ). The factors that most influence on the elderly to perform routine blood pressure control is taking antihypertensive medication ( $p=0.014$ and $\operatorname{Exp}(B)=45.5)$. A controlled blood pressure can reduce the risk factors of cardiovascular disease. To keep improving and maintaining the quality of the elderly can be done through activities in Posyandu Lansia with health education, monitoring the elderly who suffer from hypertension, and peer group .
\end{abstract}

Keywords : hypertension, blood pressure control, elderly

\section{PENDAHULUAN}

Pertambahan jumlah penduduk lansia di Indonesia dalam kurun waktu 1990-2010 tergolong sangat cepat. Pada tahun 2000, jumlah penduduk lansia sekitar 14,4 juta $(7,18 \%)$, dengan Umur Harapan Hidup (UHH) 64,5 tahun; Antara tahun 2006 sampai 2010 terjadi peningkatan jumlah penduduk lansia sebesar 4,9 juta $(0,87 \%)$, sejalan dengan peningkatan UHH dari 66,2 tahun pada tahun 2006 meningkat menjadi 67,4 tahun pada tahun 2010; Sedangkan pada tahun 2020 jumlah penduduk lansia diproyeksikan akan bertambah menjadi 28,8 juta atau sebesar 11,34 $\%$ dari 254 juta jumlah penduduk, dengan UHH yaitu 71,1 tahun (BPS, 2007). DKI Jakarta mengalami permasalahan berkaitan dengan peningkatan jumlah penduduk lansia dari tahun ke tahun. Jumlah penduduk lansia tahun 2010 sebesar 590.073 (9,61\%). Berdasarkan hasil Riskesdas tahun 2007 menunjukkan penyakit terbanyak yang dialami lansia adalah hipertensi, gangguan sendi, katarak, stroke, penyakit jantung, diabetes mellitus dan gangguan mental emosional.

Hipertensi merupakan suatu penyakit yang ditandai dengan tekanan darah di atas normal, umumnya tidak menimbulkan gejala, sehingga sering disebut sebagai silent 
killer. Diperkirakan terdapat $76 \%$ kasus hipertensi di masyarakat yang belum terdiagnosis, dalam hal ini seseorang tidak tahu bahwa dirinya mengidap hipertensi (http://darahtinggi.info/ diakses tanggal 2 September 2013).

WHO menyebutkan proporsi seseorang terkena tekanan darah tinggi meningkat seiring bertambahnya umur yaitu 1 dalam 10 orang pada usia 2030 -an tahun dan 5 dari 10 orang pada usia 50-an tahun. Karena itu, deteksi dini sangat penting dilakukan dan setiap orang dewasa harus tahu tekanan darah dan menjaganya dalam level yang normal, yaitu 120/80 mmHg (http://www.tempo.co/ diakses tanggal 2 September 2013).

Berdasarkan Profil Kesehatan di Indonesia tahun 2010 tergambar peningkatan kasus hipertensi berupa hipertensi primer yang memerlukan rawat inap sebanyak 19.874 dan meninggal dunia sebanyak 955, sedangkan untuk kasus baru tahun 2010 yang memerlukan rawat jalan sebanyak 80.615. Data Riskesdas (2007) menyatakan bahwa prevalensi nasional penderita hipertensi pada penduduk umur lebih dari 18 tahun sebesar $29.8 \%$. Penyebab kematian utama ketiga (6.8 \%) untuk semua umur setelah stroke (15.4\%) dan TB Paru $(7.5 \%)$. Pada wanita untuk kelompok umur 45-54 tahun mengalami hipertensi lebih tinggi sebesar $8.6 \%$ dari laki-laki yaitu $8 \%$.

Makin tingginya angka kejadian hipertensi di atas dan dampak yang ditimbulkannya membutuhkan dukungan dari semua pihak terutama keluarga sebagai support system bagi penderita dan pelayanan kesehatan terdekat yaitu Posyandu Lansia yang berada di masyarakat. Sebagai wujud nyata pelayanan sosial dan kesehatan pada kelompok usia lanjut ini, pemerintah telah mencanangkan pelayanan pada lansia melalui beberapa jenjang. Pelayanan kesehatan di tingkat masyarakat adalah Posyandu lansia, pelayanan kesehatan lansia tingkat dasar adalah Puskesmas, dan pelayanan kesehatan tingkat lanjutan adalah Rumah Sakit. Posyandu lansia adalah pos pelayanan terpadu untuk masyarakat usia lanjut di suatu wilayah tertentu yang sudah disepakati, yang digerakkan oleh masyarakat dimana mereka bisa mendapatkan pelayanan kesehatan Posyandu lansia merupakan pengembangan dari kebijakan pemerintah melalui pelayanan kesehatan bagi lansia yang penyelenggaraannya melalui program Puskesmas dengan melibatkan peran serta para lansia, keluarga, tokoh masyarakat dan organisasi sosial dalam penyelenggaraannya.

Berdasarkan hasil penelitian Ekarini (2011) dikatakan ada berbagai masalah yang menyebabkan pasien hipertensi tidak melakukan kontrol tekanan darah yaitu sebagian besar pasien tidak merasakan adanya keluhan, kurangnya pengetahuan tentang bahaya penyakit hipertensi, dan tidak ada waktu untuk mengunjungi fasilitas kesehatan.

\section{METODOLOGI}

Jenis penelitian ini adalah noneksperimen (observasional) dengan pendekatan cross sectional yang bertujuan untuk mendapatkan gambaran hubungan di antara variabel independen terhadap variabel dependen. Populasi dalam penelitian ini adalah seluruh lansia yang datang pada saat Posyandu Lansia di Wilayah Puskesmas Kecamatan Pulo Gadung Jakarta Timur. Sampel berjumlah 46 responden. Alat pengumpul data menggunakan instrumen A yang 
terdiri dari Karakteristik lansia yaitu usia, jenis kelamin, status pendidikan, tinggal serumah, riwayat hipertensi, menderita hipertensi, minum obat hipertensi, waktu dan tempat kontrol tekanan darah, kebiasaan merokok, makan yang asin-asin, kurang tidur, pernah mendapatkan penyuluhan kesehatan tentang hipertensi dan adanya manfaat dari Posyandu Lansia. Instrumen $B$ dan $C$ yaitu sikap dan perilaku lansia dalam penanganan hipertensi.

Tabel 1. Uji Statistik yang digunakan

\begin{tabular}{|c|c|c|c|}
\hline $\mathrm{No}$ & $\begin{array}{c}\text { Variabel } \\
\text { Independen }\end{array}$ & $\begin{array}{c}\text { Variabel } \\
\text { Dependen }\end{array}$ & $\begin{array}{l}\text { Uji } \\
\text { Statis } \\
\text { tik }\end{array}$ \\
\hline 1. & $\begin{array}{l}\text { Usia, Usia, } \\
\text { status pendidikan, } \\
\text { jenis kelamin, } \\
\text { riwayat hipertensi, } \\
\text { minum obat } \\
\text { hipertensi, } \\
\text { lama menderita } \\
\text { hipertensi, } \\
\text { kebiasaan merokok, } \\
\text { makan asin, penkes, } \\
\text { manfaat posyandu } \\
\text { lansia, perilaku } \\
\text { sikap dan lansia } \\
\text { (Katagorik) }\end{array}$ & $\begin{array}{l}\text { Kontrol } \\
\text { tekanan } \\
\text { darah (Kata } \\
\text { gorik) }\end{array}$ & $\begin{array}{l}\text { Chi- } \\
\text { Square }\end{array}$ \\
\hline 2. & $\begin{array}{l}\text { Usia, status } \\
\text { pendidikan, } \\
\text { jenis kelamin, } \\
\text { riwayat hipertensi, } \\
\text { minum obat } \\
\text { hipertensi, } \\
\text { lama menderita } \\
\text { hipertensi, } \\
\text { kebiasaan merokok, } \\
\text { makan asin, penkes, } \\
\text { manfaat posyandu } \\
\text { lansia, sikap dan } \\
\text { perilaku lansia } \\
\text { (Katagorik) }\end{array}$ & $\begin{array}{l}\text { Kontrol } \\
\text { Tekanan } \\
\text { darah } \\
\text { (kata } \\
\text { gorik) }\end{array}$ & $\begin{array}{l}\text { Regresi } \\
\text { Logis } \\
\text { tik }\end{array}$ \\
\hline
\end{tabular}

\section{HASIL PENELITIAN}

\section{Analisis Univariat}

Tabel 2. Distribusi karakteristik lansia di Posyandu Lansia Puskesmas

Kecamatan Pulo Gadung Tahun 2014

\begin{tabular}{|l|c|c|}
\hline \multicolumn{1}{|c|}{$\begin{array}{c}\text { Karakteristik } \\
\text { lansia }\end{array}$} & Frekue & $\begin{array}{c}\text { Persentase } \\
(\%)\end{array}$ \\
\hline Usia & N=46) & \\
1.Pra lansia $(<60$ thn $)$ & 18 & 39,1 \\
2.Lansia $(>=60$ thn) & 28 & 60,9 \\
\hline Jenis kelamin & & \\
1.Laki-laki & 3 & 6,5 \\
2.Perempuan & 43 & 93,5 \\
& & \\
\hline Tingkat pendidikan & & \\
1.Tidak pernah & 2 & 4,3 \\
& 7 & 15,2 \\
2.Tamat SD & 13 & 28,3 \\
3.Tamat SMP & 23 & 50,0 \\
4.Tamat SMA & 1 & 2,2 \\
5.Tamat PT & & \\
& & \\
\hline Tinggal serumah & 21 & 45,7 \\
1. pasangan & 11 & 23,9 \\
2. anak kandung & 14 & 30,4 \\
3. keluarga besar & & \\
\hline
\end{tabular}


Tabel 3. Distribusi karakteristik lansia di Posyandu Lansia Puskesmas Kecamatan Pulo Gadung Tahun 2014

\begin{tabular}{|c|c|c|}
\hline Karakteristik lansia & $\begin{array}{c}\text { Frekuensi } \\
\quad(n=46)\end{array}$ & $\begin{array}{c}\text { Persentase } \\
(\%)\end{array}$ \\
\hline $\begin{array}{l}\text { Ada riwayat hipertensi } \\
\text { di keluarga } \\
\text { 1. Ya } \\
\text { 2. Tidak }\end{array}$ & $\begin{array}{l}23 \\
23\end{array}$ & $\begin{array}{l}50,0 \\
50,0\end{array}$ \\
\hline $\begin{array}{l}\text { Kebiasaan merokok } \\
\text { 1. Ya } \\
\text { 2. Tidak }\end{array}$ & $\begin{array}{c}2 \\
44\end{array}$ & $\begin{array}{c}4,3 \\
95,7\end{array}$ \\
\hline $\begin{array}{l}\text { Suka makan asin-asin } \\
\text { 1. Ya } \\
\text { 2. Tidak }\end{array}$ & $\begin{array}{l}26 \\
20\end{array}$ & $\begin{array}{l}56,5 \\
43,5\end{array}$ \\
\hline $\begin{array}{l}\text { Saat ini kurang tidur/ } \\
\text { kurang istirahat } \\
\text { 1. Ya } \\
\text { 2. Tidak }\end{array}$ & $\begin{array}{l}24 \\
22\end{array}$ & $\begin{array}{l}52,2 \\
47,8\end{array}$ \\
\hline $\begin{array}{l}\text { Pernah mendapat } \\
\text { penkes hipertensi } \\
\text { 1. Ya } \\
\text { 2. Tidak }\end{array}$ & $\begin{array}{c}7 \\
39 \\
\end{array}$ & $\begin{array}{l}15,2 \\
84,8 \\
\end{array}$ \\
\hline $\begin{array}{ll}\text { Posyandu Lansia } \\
\text { bermanfaat } \\
\text { 1. Ya } \\
\text { 2. Tidak } \\
\end{array}$ & $\begin{array}{c}42 \\
4 \\
\end{array}$ & $\begin{array}{c}91,3 \\
8,7 \\
\end{array}$ \\
\hline
\end{tabular}

Tabel 4. Distribusi lansia berdasarkan kontrol tekanan darah di Posyandu Lansia Puskesmas Kecamatan Pulo Gadung Tahun 2014

\begin{tabular}{|c|c|c|}
\hline $\begin{array}{l}\text { Karakteristik } \\
\text { lansia }\end{array}$ & \begin{tabular}{|} 
Frekuensi \\
$\mathrm{N}=46)$
\end{tabular} & $\begin{array}{l}\text { Persen } \\
\%)\end{array}$ \\
\hline $\begin{array}{l}\text { Melakukan } \\
\text { kontrol tekanan } \\
\text { darah rutin } \\
\text { 1. Ya } \\
\text { 2. Tidak }\end{array}$ & $\begin{array}{l}23 \\
23\end{array}$ & $\begin{array}{l}50,0 \\
50,0\end{array}$ \\
\hline Jumlah & 46 & 100,0 \\
\hline
\end{tabular}

Tabel 5. Distribusi karakteristik lansia terkait hipertensi di Posyandu Lansia Puskesmas Kecamatan Pulo Gadung Tahun 2014

\begin{tabular}{|l|c|c|}
\hline $\begin{array}{l}\text { Karakteristik } \\
\text { lansia }\end{array}$ & $\begin{array}{c}\text { Frekuensi } \\
(\mathrm{n}=33)\end{array}$ & $\begin{array}{r}\text { Persen } \\
\text { tase }(\%)\end{array}$ \\
\hline $\begin{array}{l}\text { Menderita } \\
\text { 1. Ya }\end{array}$ & 33 & 71,7 \\
2. Tidak & 13 & 28,3 \\
\hline $\begin{array}{l}\text { Lama } \\
\text { Hipertensi }\end{array}$ & 12 & 36,4 \\
$\begin{array}{l}\text { 1.<1 thn } \\
\text { 2. 1-5 thn }\end{array}$ & 6 & 0,2 \\
3.>5 thn & 15 & 63,4 \\
\hline $\begin{array}{l}\text { Pertama kali } \\
\text { mengetahui } \\
\begin{array}{l}\text { Menderita } \\
\text { hipertensi }\end{array}\end{array}$ & & \\
$\begin{array}{l}\text { 1.Setelah di } \\
\text { periksa ke Pusk }\end{array}$ & 6 & 18,2 \\
$\begin{array}{l}\text { 2.Setelah } \\
\text { diperiksa ke RS }\end{array}$ & 10 & 30,3 \\
$\begin{array}{l}\text { 3.Setelah } \\
\text { diperiksa ke }\end{array}$ & 14 & 42,4 \\
$\begin{array}{l}\text { Posyandu } \\
\text { Lansia } \\
\text { 4.Lainnya }\end{array}$ & & \\
\hline $\begin{array}{l}\text { Minum Obat } \\
\text { hipertensi }\end{array}$ & & \\
$\begin{array}{l}\text { 1. Ya } \\
\text { 2. Tidak }\end{array}$ & 14 & 42,4 \\
\hline
\end{tabular}


Tabel 6. Distribusi lansia berdasarkan sikap dan perilaku lansia dalam penanganan hipertensi di Posyandu Lansia Puskesmas Kecamatan Pulo Gadung Tahun 2014

\begin{tabular}{|l|c|c|}
\hline \multicolumn{1}{|c|}{$\begin{array}{c}\text { Sikap } \\
\text { dan } \\
\text { Perilaku }\end{array}$} & $\begin{array}{c}\text { Frekuensi } \\
(\mathrm{N}=33)\end{array}$ & $\begin{array}{c}\text { Persentase } \\
(\%)\end{array}$ \\
\hline $\begin{array}{l}\text { Sikap } \\
\text { lansia } \\
\text { mendukung } \\
\text { penanganan } \\
\text { hipertensi } \\
\text { 1. Ya }\end{array}$ & 21 & 63,6 \\
2. Tidak & 12 & 36,4 \\
\hline $\begin{array}{l}\text { Perilaku } \\
\text { lansia } \\
\text { mendukung } \\
\text { penanganan } \\
\text { hipertensi }\end{array}$ & & \\
1. Ya & 13 & 39,4 \\
2. Tidak & 20 & 60,6 \\
\hline
\end{tabular}

Tabel 7. Hubungan karakteristik lansia dengan kontrol tekanan darah pada lansia di Posyandu Lansia Puskesmas Kec. Pulo Gadung Tahun 2014

\begin{tabular}{|c|c|c|c|c|c|c|c|c|}
\hline \multirow[t]{3}{*}{ Variabel } & \multicolumn{4}{|c|}{ Kontrol Tekanan Darah } & \multirow{2}{*}{\multicolumn{2}{|c|}{ Total }} & \multirow{3}{*}{$\begin{array}{c}p \\
\text { value }\end{array}$} & \multirow[t]{3}{*}{ OR $(95 \% \mathrm{CI})$} \\
\hline & \multicolumn{2}{|c|}{$\mathrm{Ya}$} & \multicolumn{2}{|c|}{ Tidak } & & & & \\
\hline & $\mathrm{n}$ & $\%$ & $\mathrm{n}$ & $\%$ & $\mathrm{n}$ & $\%$ & & \\
\hline $\begin{array}{l}\text { Usia } \\
1 .<60 \text { thn } \\
\text { 2. }>=60 \text { thn }\end{array}$ & $\begin{array}{l}9 \\
14\end{array}$ & $\begin{array}{l}50,0 \\
50,0\end{array}$ & $\begin{array}{l}9 \\
14\end{array}$ & $\begin{array}{l}50,0 \\
50,0\end{array}$ & $\begin{array}{l}18 \\
28\end{array}$ & $\begin{array}{l}100 \\
100\end{array}$ & 1,000 & $1,000(0,306-3,268)$ \\
\hline $\begin{array}{l}\text { Jenis kelamin } \\
\text { 1.Laki-laki } \\
\text { 2.Perempuan }\end{array}$ & $\begin{array}{l}2 \\
21\end{array}$ & $\begin{array}{l}66,7 \\
48,8\end{array}$ & $\begin{array}{l}1 \\
22\end{array}$ & $\begin{array}{l}33,3 \\
51,2\end{array}$ & $\begin{array}{l}3 \\
43\end{array}$ & $\begin{array}{l}100 \\
100\end{array}$ & 1,000 & $2,095(0,177-24,865)$ \\
\hline $\begin{array}{l}\text { Kurang tidur/ } \\
\text { Kurang istirahat } \\
\text { 1.Ya } \\
\text { 2.Tidak }\end{array}$ & $\begin{array}{l}12 \\
11\end{array}$ & $\begin{array}{l}50,0 \\
50,0\end{array}$ & $\begin{array}{l}12 \\
11\end{array}$ & $\begin{array}{l}50,0 \\
50,0\end{array}$ & $\begin{array}{l}24 \\
22\end{array}$ & $\begin{array}{l}100 \\
100\end{array}$ & 1,000 & $1,000(0,314-3,180)$ \\
\hline $\begin{array}{l}\text { Suka makan asin- } \\
\text { asin } \\
\text { 1. Ya } \\
\text { 2. Tidak }\end{array}$ & $\begin{array}{l}10 \\
13\end{array}$ & $\begin{array}{l}38,5 \\
65,0\end{array}$ & $\begin{array}{l}16 \\
7\end{array}$ & $\begin{array}{l}61,5 \\
35,0\end{array}$ & $\begin{array}{l}26 \\
20\end{array}$ & $\begin{array}{l}100 \\
100\end{array}$ & 0.137 & $0,337(0,100-1,131)$ \\
\hline
\end{tabular}


Tabel di atas menggambarkan bahwa lansia dengan usia $\geq 60$ tahun lebih banyak yang melakukan kontrol tekanan darah sebanyak 14 lansia $(50,0 \%)$ dibandingkan dengan usia kurang dari 60 tahun sebanyak 9 lansia $(50,0 \%)$. Hasil uji statistik diperoleh $p$ value $=1,000$ yang berarti tidak ada hubungan bermakna antara usia lansia dengan melakukan kontrol tekanan darah rutin.

Proporsi lansia yang berjenis kelamin perempuan yang tidak melakukan kontrol tekanan darah lebih banyak sebesar 51,2 \% dari lansia perempuan yang melakukan kontrol tekanan darah (48,8 \%). Hasil uji statistik diperoleh $\mathrm{p}$ value $=1,000$ yang berarti tidak ada hubungan bermakna antara jenis kelamin dengan melakukan kontrol tekanan darah rutin, tetapi dari nilai OR diketahui bahwa lansia perempuan mempunyai peluang 2,095 kali untuk melakukan kontrol tekanan darah dibandingkan dengan lansia laki-laki.

Hasil analisis hubungan antara suka makan yang asin-asin dan melakukan kontrol tekanan darah diketahui bahwa proporsi responden yang suka makan yang asin-asin tetapi tidak melakukan kontrol tekanan darah sebesar $61,5 \%$. Hasil uji statistik diperoleh $\mathrm{p}$ value $=0,137$ yang berarti tidak ada hubungan bermakna antara suka makan yang asin-asin dengan melakukan kontrol tekanan darah.

Tabel 8. Hubungan karakteristik lansia dengan kontrol tekanan darah pada lansia di Posyandu Lansia Puskesmas Kec. Pulo Gadung Tahun 2014

\begin{tabular}{|c|c|c|c|c|c|c|c|c|c|}
\hline \multicolumn{10}{|c|}{$(\mathrm{N}=46)$} \\
\hline \multirow[t]{3}{*}{ Variabel } & \multicolumn{4}{|c|}{ Kontrol Tekanan Darah } & \multicolumn{2}{|c|}{ Total } & \multirow{3}{*}{$\begin{array}{c}p \\
\text { value }\end{array}$} & \multicolumn{2}{|c|}{ OR $(95 \% \mathrm{CI})$} \\
\hline & \multicolumn{2}{|c|}{ Ya } & \multicolumn{2}{|c|}{ Tidak } & & & & & \\
\hline & $\mathrm{N}$ & $\%$ & $\mathrm{~N}$ & $\%$ & $\mathrm{~N}$ & $\%$ & & & \\
\hline Kebiasaan & & & & & & & \multirow{3}{*}{1,000} & \multirow{3}{*}{1,000} & \multirow{3}{*}{$(0,059-$} \\
\hline 1. Ya & 1 & 50,0 & 1 & 50,0 & 2 & 100 & & & \\
\hline 2. Tidak & 22 & 50,0 & 22 & 50,0 & 44 & 100 & & & \\
\hline \multirow{2}{*}{$\begin{array}{l}\text { Status pendidikan } \\
\text { 1.Rendah } \\
\text { 2.Tinggi }\end{array}$} & & & & & & & \multirow[b]{2}{*}{0,140} & \multirow[b]{2}{*}{2,917} & \multirow[b]{2}{*}{$(0,879-$} \\
\hline & 14 & 63,6 & 8 & 36,4 & 22 & 100 & & & \\
\hline \multirow{3}{*}{$\begin{array}{l}\text { Pernah } \\
\text { mendapatkan } \\
\text { penkes hipertensi } \\
\text { 1.Ya } \\
\text { 2.Tidak }\end{array}$} & & & & & & & \multirow{3}{*}{0,096} & \multirow{3}{*}{7,765} & \multirow{3}{*}{$(0,852-$} \\
\hline & 6 & 85,7 & 1 & 14,3 & 7 & 100 & & & \\
\hline & 17 & 43,6 & 22 & 56,4 & 39 & 100 & & & \\
\hline \multicolumn{10}{|l|}{ Posyandu lansia } \\
\hline 1. $\mathrm{Ya}$ & 22 & 52,4 & 20 & 47,6 & 42 & 100 & \multirow[t]{2}{*}{0.608} & \multirow[t]{2}{*}{3,300} & \multirow[t]{2}{*}{$(0,317-$} \\
\hline 2. Tidak & 1 & 25,0 & 3 & 75,0 & 4 & 100 & & & \\
\hline
\end{tabular}


Tabel di atas menggambarkan bahwa lansia dengan tingkat pendidikan tinggi lebih banyak yang tidak melakukan kontrol tekanan darah $(62,5 \%)$ dibandingkan dengan lansia yang status pendidikannya rendah. Hasil uji statistik diperoleh $p$ value $=0,140$ yang berarti tidak ada hubungan bermakna antara status pendidikan lansia dengan melakukan kontrol tekanan darah rutin.

Proporsi lansia yang tidak pernah mendapatkan penyuluhan kesehatan tentang hipertensi, tidak melakukan kontrol tekanan darah lebih banyak sebesar 56,4 \% dibandingkan dengan yang melakukan kontrol tekanan darah (43,6 \%). Hasil uji statistik diperoleh $\mathrm{p}$ value $=0.096$ yang berarti tidak ada hubungan bermakna antara pernah mendapatkan penyuluhan kesehatan tentang hipertensi dengan melakukan kontrol tekanan darah rutin.

Proporsi lansia yang memilih ada manfaat dari Posyandu Lansia dengan melakukan kontrol tekanan darah sebesar 52,4 \% dibandingkan dengan tidak melakukan kontrol tekanan darah $(47,6 \%)$.

Tabel 9. Hubungan karakteristik lansia hipertensi dengan kontrol tekanan darah pada lansia di Posyandu Lansia Puskesmas Kec. Pulo Gadung Tahun $2014(\mathrm{~N}=33)$

\begin{tabular}{|c|c|c|c|c|c|c|c|c|}
\hline \multirow[t]{3}{*}{ Variabel } & \multicolumn{4}{|c|}{ Kontrol Tekanan Darah } & \multirow{2}{*}{\multicolumn{2}{|c|}{ Total }} & \multirow{3}{*}{$\begin{array}{c}p \\
\text { value }\end{array}$} & \multirow[t]{3}{*}{ OR $(95 \% \mathrm{CI})$} \\
\hline & \multicolumn{2}{|c|}{$\mathrm{Ya}$} & \multicolumn{2}{|c|}{ Tidak } & & & & \\
\hline & $\mathrm{N}$ & $\%$ & $\mathrm{~N}$ & $\%$ & $\mathrm{~N}$ & $\%$ & & \\
\hline $\begin{array}{l}\text { Minum } \\
\text { obat hipertensi } \\
\text { 1. Ya } \\
\text { 2. Tidak }\end{array}$ & $\begin{array}{c}13 \\
8\end{array}$ & $\begin{array}{l}92,9 \\
42,1\end{array}$ & $\begin{array}{c}1 \\
11\end{array}$ & $\begin{array}{c}7,1 \\
57,9\end{array}$ & $\begin{array}{l}14 \\
19\end{array}$ & $\begin{array}{l}100 \\
100\end{array}$ & 0,004 & $17,875(1,925-165,992)$ \\
\hline $\begin{array}{l}\text { Ada } \\
\text { riwayat hipertens } \\
\text { di keluarga } \\
\text { 1.Ya } \\
\text { 2.Tidak }\end{array}$ & $\begin{array}{c}16 \\
7\end{array}$ & $\begin{array}{l}69,6 \\
30,4\end{array}$ & $\begin{array}{c}7 \\
16\end{array}$ & $\begin{array}{l}30,4 \\
69,6\end{array}$ & $\begin{array}{l}23 \\
23\end{array}$ & $\begin{array}{l}100 \\
100\end{array}$ & 0,018 & $5,224(1,488-18,347)$ \\
\hline $\begin{array}{l}\text { Lama } \\
\text { menderita } \\
\text { 1 thn } \\
\text { 2. } 1-5 \text { thn } \\
\text { 3. }>5 \text { thn } \\
\text { 4. tidak menderita }\end{array}$ & $\begin{array}{c}8 \\
3 \\
10 \\
2\end{array}$ & $\begin{array}{l}66,7 \\
50,0 \\
66,7 \\
15,4\end{array}$ & $\begin{array}{c}4 \\
3 \\
5 \\
11\end{array}$ & $\begin{array}{l}33,3 \\
50,0 \\
33,3 \\
84,6\end{array}$ & $\begin{array}{c}12 \\
6 \\
15 \\
13\end{array}$ & $\begin{array}{l}100 \\
100 \\
100 \\
100\end{array}$ & 0,026 & - \\
\hline
\end{tabular}

Proporsi lansia yang minum obat hipertensi lebih besar 92,9\% melakukan kontrol tekanan darah rutin dibandingkan dengan yang tidak sebesar 7,1\%. Dari hasil uji statistik didapatkan $p$ value 0,004 yang berarti ada hubungan bermakna antara minum obat hipertensi dengan melakukan 
kontrol tekanan darah rutin. Dari nilai OR dapat disimpulkan bahwa lansia yang minum obat hipertensi berpeluang 17,875 kali untuk melakukan kontrol tekanan darah rutin.

Proporsi lansia yang memiliki riwayat hipertensi lebih besar $69,6 \%$ melakukan control tekanan darah rutin dibandingkan dengan yang tidak sebesar 30,4\%. Dari hasil uji statistik didapatkan $p$ value 0,018 yang berarti ada hubungan bermakna antara lansia yang memiliki riwayat hipertensi dengan melakukan kontrol tekanan darah. Dari nilai OR dapat disimpulkan bahwa lansia yang memiliki riwayat hipertensi berpeluang 5,224 kali untuk melakukan kontrol tekanan darah rutin.

Proporsi lansia yang menderita hipertensi lebih dari 5 tahun melakukan kontrol tekanan darah rutin sebesar $66,7 \%$ dibandingkan dengan yang tidak sebesar 33,3\%. Dari hasil uji statistik didapatkan $\mathrm{p}$ value 0,026 yang berarti ada hubungan bermakna antara lama menderita hipertensi dengan melakukan kontrol tekanan darah rutin.

\section{Analisis Multivariat}

Tabel 10. Hasil analisis multivariat hubungan variabel independen dengan variabel dependen di Posyandu Lansia

Pusk Kec. Pulo Gadung tahun 2014

\begin{tabular}{|c|l|c|}
\hline $\mathrm{N}$ & \multicolumn{1}{|c|}{ Variabel Independen } & $\mathrm{P}$ value \\
\hline 1 & Minum obat hipertensi & 0,004 \\
\hline 2 & Ada riwayat hipertensi & 0,018 \\
\hline 3 & Menderita hipertensi lebih & 0,026 \\
\hline
\end{tabular}

Tabel 11. Model akhir regresi logistik

\begin{tabular}{|c|c|c|c|c|}
\hline Model & B & Sig & $\operatorname{Exp}(\mathrm{B})$ & $\begin{array}{c}95 \% \\
\text { CI }\end{array}$ \\
\hline $\begin{array}{c}\text { Lama } \\
\text { menderita } \\
\text { hipertensi }\end{array}$ & 1,100 & 0,138 & 3,005 & $\begin{array}{c}0,702- \\
12,861\end{array}$ \\
\hline \begin{tabular}{|c|} 
Minum \\
Obat \\
hipertensi
\end{tabular} & 3,818 & 0,014 & 45,535 & $\begin{array}{l}2,141- \\
968,315\end{array}$ \\
\hline
\end{tabular}

Tabel di atas menunjukkan nilai Exp (B) dari variabel minum obat hipertensi sebesar 45,535 dengan $\mathrm{p}$ value 0,014 . Variabel yang paling besar pengaruhnya terhadap melakukan kontrol tekanan darah rutin adalah minum obat hipertensi.

\section{PEMBAHASAN}

\section{Kontrol tekanan darah pada lansia}

Hasil penelitian menunjukkan bahwa sebesar 50,0 \% lansia melakukan kontrol tekanan darah rutin dan 50,0\% nya lagi tidak melakukan kontrol tekanan darah secara rutin. Padahal dari hasil penelitian juga didapatkan bahwa lansia yang menderita hipertensi sebesar 71,7 \%; banyak yang suka makan asin-asin (56,5\%); kurang tidur $(52,2 \%)$; lama menderita hipertensi lebih dari 5 tahun $(63,4$ $\%$ ); perilaku lansia tidak mendukung penanganan hipertensi (60,6 \%) dan tidak pernah mendapatkan penyuluhan kesehatan tentang hipertensi $(84,8$ $\%$ ).

Dukungan petugas kesehatan sangat penting bagi penderita hipertensi terutama dalam hal penyuluhan. Hal ini disebabkan masih banyaknya penderita hipertensi yang kurang mengetahui gejala dan penyebab 
penyakit tersebut. Pendidikan kesehatan bertujuan untuk meningkatkan status kesehatan, mencegah timbulnya penyakit dan bertambahnya masalah kesehatan, mempertahankan derajat kesehatan yang sudah ada, memaksimalkan fungsi dan peran pasien selama sakit, serta membantu pasien dan keluarga untuk mengatasi masalah kesehatan (Notoatmodjo, 2003). Penelitian ini sejalan dengan penelitian Ekarini (2011) yang menyatakan bahwa dukungan petugas kesehatan sangat diperlukan untuk mensosialisasikan pentingnya menjalani pengobatan yang teratur bagi pasien hipertensi. Adanya dukungan petugas kesehatan berupa edukasi dapat menambah pengetahuan penderita hipertensi mengenai penyakit yang dideritanya seperti pentingnya melakukan pengobatan secara rutin untuk menghindari terjadinya komplikasi.

Adanya penyuluhan kesehatan tentang hipertensi yang diberikan oleh petugas kesehatan sangat sesuai dengan penelitian Annisa (2014) yang menyatakan bahwa ada hubungan pengetahuan, motivasi, dukungan petugas kesehatan dan dukungan keluarga dengan kepatuhan berobat hipertensi.

Hasil penelitian terkait perilaku lansia yang kurang mendukung dalam penanganan hipertensi antara lain dalam hal tidak melakukan kontrol tekanan darah, tidak menghindari makanan yang asin dan berlemak, tidak minum obat yang diresepkan secara teratur, tidak melakukan olahraga dan tidak mengikuti kegiatan sosial di masyarakat. Hal ini sesuai dengan The Eighth Report of The Joint National Committee on Prevention, Detection, Evaluation, and Treatment of High Blood Pressure (JNC VIII) yang mengemukakan bahwa jangka waktu terapi antihipertensi adalah seumur hidup. Tujuan terapi antihipertensi adalah menstabilkan tekanan darah sehingga menurunkan mortalitas dan morbiditas yang berhubungan dengan kerusakan organ target seperti penyakit kardiovaskular, cerebrovaskular, gagal jantung, dan penyakit ginjal. Kepatuhan minum obat berperan dalam mengontrol tekanan darah dan mencegah terjadinya komplikasi hipertensi. Kepatuhan $80 \%$ terhadap regimen obat antihipertensi dapat menurunkan tekanan darah ke tingkat normal dan kepatuhan $\leq 50 \%$ tidak efektif dan adekuat untuk menurunkan tekanan darah (Marshall dkk., 2012 dalam Hairunisa, 2014).

\section{Hubungan antara minum obat hipertensi dengan kontrol tekanan darah}

Berdasarkan hasil penelitian ditemukan adanya hubungan antara minum obat hipertensi dengan melakukan kontrol tekanan darah dengan $p$ value 0,004 dimana hasil ini mendapatkan presentase sebesar 92,9 $\%$. Hasil ini mendukung penelitian Hairunisa (2014) yang menyatakan terdapat hubungan bermakna antara kepatuhan minum obat dan diet dengan tekanan darah yang terkontrol.

Data WHO (2011, dalam Hairunisa, 2014) dari $50 \%$ penderita hipertensi yang diketahui hanya $25 \%$ yang mendapat pengobatan dan hanya $12,5 \%$ yang diobati dengan baik. Diperkirakan pada tahun 2025 kasus hipertensi terutama di negara berkembang akan mengalami peningkatan sekitar $80 \%$ dari 639 juta kasus di tahun 2000, menjadi 1,15 milyar kasus. Riset Kesehatan Dasar (Riskesdas) tahun 2007 melaporkan bahwa prevalensi 
hipertensi pada penduduk umur 18 tahun keatas di Indonesia cukup tinggi yaitu mencapai $31,7 \%$ dimana penduduk yang mengetahui dirinya menderita hipertensi hanya $7,2 \%$ dan yang minum obat antihipertensi hanya $0,4 \%$.

Peningkatan jumlah lansia akan memberi dampak pada peningkatan kebutuhan sarana prasarana kesehatan bagi lansia. Salah satu layanan kesehatan lansia yang efektif dalam memberikan pelayanan kesehatan lansia dan diselenggarakan melalui program Puskesmas adalah Posyandu Lansia. Salah satu kegiatan posyandu lansia adalah pemberian penyuluhan tentang masalah kesehatan lansia termasuk tentang penyakit-penyakit degeneratif yang salah satunya adalah hipertensi. Hal ini didukung oleh hasil penelitian di atas yaitu lansia menjawab bahwa Posyandu Lansia sangat bermanfaat $(91,3 \%)$ dimana banyak kegiatan dan pemeriksaan yang dilakukan.

\section{Hubungan antara ada riwayat hipertensi dengan kontrol tekanan darah}

Hasil penelitian menunjukkan ada hubungan bermakna antara riwayat hipertensi dengan melakukan kontrol tekanan darah $(\mathrm{p}$ value $=0,018)$ dimana hasil ini menyatakan bahwa lansia yang memiliki riwayat hipertensi dalam keluarga akan melakukan kontrol tekanan darah secara rutin. Hasil ini sesuai dengan pendapat Jaya, 2009 dalam Rani, 2013 dan Smelzter, 2001 yang mengatakan bahwa individu yang keluarga atau orang tua mengalami hipertensi cenderung memiliki kemungkinan lebih besar mengalami hipertensi dibandingkan dengan individu yang tidak memiliki keluarga yang mengalami hipertensi. Dan ini juga merupakan bagian dari hipertensi primer (esensial) yang penyebab hipertensi tidak diketahui yaitu genetika (keturunan).

\section{Hubungan antara lama menderita hipertensi dengan kontrol tekanan darah}

Hasil penelitian menunjukkan ada hubungan bermakna antara lama menderita hipertensi dengan melakukan kontrol tekanan darah $(\mathrm{p}$ value $=0,026$ ) dimana lansia yang menderita hipertensi lebih dari 5 tahun akan melakukan kontrol tekanan darahnya secara rutin. Lansia yang menderita lama ini juga minum obat dan melakukan kontrol tekanan darahnya. Hasil ini memperkuat pendapat dalam Rani (2013) yang menyatakan bahwa $50 \%$ penderita hipertensi tidak mematuhi anjuran petugas kesehatan untuk mengonsumsi obat menyebabkan banyak pasien hipertensi yang tidak dapat mengendalikan tekanan darahnya dan berujung pada kematian.

Berdasarkan hasil penelitian status pendidikan yang tidak ada hubungan dengan melakukan kontrol tekanan darah dimana lansia yang status pendidikan tinggi justru tidak melakukan kontrol tekanan darah sebesar $62,5 \%$. Hal ini tidak sejalan dengan penelitian Ekarini (2011) yang menyatakan bahwa ada hubungan yang bermakna antara tingkat pendidikan dengan tingkat kepatuhan klien hipertensi dalam menjalani pengobatan.

\section{KESIMPULAN DAN SARAN}

Ada hubungan yang bermakna antara minum obat hipertensi dengan melakukan kontrol tekanan darah rutin. Lansia yang minum obat hipertensi berpeluang 17, 875 kali untuk melakukan kontrol tekanan darah rutin. Ada hubungan yang bermakna antara memiliki riwayat 
hipertensi dengan melakukan kontrol tekanan darah rutin. Lansia yang memiliki riwayat hipertensi berpeluang 5,224 kali untuk melakukan kontrol tekanan darah rutin. Ada hubungan yang bermakna antara lama menderita hipertensi dengan melakukan kontrol tekanan darah rutin. Variabel yang paling besar pengaruhnya untuk melakukan kontrol tekanan darah rutin adalah minum obat hipertensi. Diharapkan pihak Puskesmas dapat eningkatkan dan mempertahankan kegiatan yang sudah dilakukan di Posyandu Lansia, melakukan cek kesehatan lansia secara berkala (hipertensi, gula darah, kolesterol, BB/ TB, diet seimbang, kebiasaan merokok), memberikan penkes tentang hipertensi dan keteraturan minum obat, melakukan pengecekan kehadiran lansia pada Posyandu Lansia, melakukan monitoring dan evaluasi terkait kegiatan Posyandu dan penanganan hipertensi di masyarakat, dan membuat kelompok sebaya/ peer group dimana lansia dalam kelompok dapat saling membantu dan mengingatkan satu sama lain.

\section{DAFTAR PUSTAKA}

Annisa, F.N., Wahiduddin.,\& Ansar. J. 2014. Faktor-faktor yang berhubungan dengan kepatuhan berobat hipertensi pada lansia di Puskesmas Pattingaloang Kota Makasar. Universitas Hasanudin: FKM.

Anonim. Hubungan antara peran keluarga terhadap perilaku pencegahan komplikasi pada lansia dengan hipertensi di Wilayah Puskesmas Kasihan II Bantul. Diakses tanggal 14
Januari 2015 dari www.thesis.umy.ac.id.

Burke, M.M., \& Laramie, J.A. 2000. Primary Care of the Older Adult. A Multidisciplinary Approach. St. Louis, Missouri: Mosby, Inc.

Burn, N., \& Grove, S.K. 2001. The Practice of Nursing Research Conduct, Critique, and Utilization. (4 $4^{\text {th }}$ edition). Philadelphia: W.B. Saunders Company.

Darmojo, R.B.\& Martono, H.H. 2004. Geriatri (Ilmu Kesehatan Usia Lanjut). Jakarta: Balai Penerbit FKUI.

Depkes RI. 2006. Pedoman pelatihan kader kelompok usia lanjut bagi petugas kesehatan. Direktorat Kesehatan Keluarga.

Ekarini, D. 2011. Faktor-faktor yang berhubungan dengan tingkat kepatuhan klien hipertensi dalam menjalani pengobatan di Puskesmas Gondangrejo Karanganyar. (online). Jurnal.stikeskusumahusada.ac.i d.

Hairunisa., Arundina.A., \& Armyanti, I. 2014. Hubungan tingkat kepatuhan minum obat dan diet dengan tekanan darah terkontrol pada penderita hipertensi lansia di Wilayah Kerja Puskesmas Perumnas I Kecamatan Pontianak Barat. Universitas Tanjungpura Pontianak: FK.

Hardywinoto \& Setiabudhi, T. 2005. Panduan Gerontologi. Tinjauan dari Berbagai Aspek. Jakarta: Penerbit PT Gramedia Pustaka Utama. 
Hastono, S.P. 2007. Analisis Data Kesehatan. Modul Pengajaran. UI: FKM.

Lueckenotte, A.G. 2000. Gerontologic Nursing. ( $2^{\text {nd }}$ Edition). St. Louis, Missouri: Mosby, Inc.

Miller, C.A. 2010. Nursing for wellness in older adult: theory and practice. $4^{\text {th }}$ Edition. Philadelphia: Lippincot.

Notoatmodjo, S. 2005. Metodologi Penelitian Kesehatan. (Edisi Revisi). Jakarta: Penerbit Rineka Cipta.

Rani Evadewi, P.K.,\& Sukmayanti, L.M.K. 2013. Kepatuhan mengonsumsi obat pasien hipertensi di Denpasar ditinjau dari kepribadian tipe A dan B. Jurnal Psikologi Udayana, Vol. 1 No. 1, 32-42.

Riasmini, M., \& Sahar, J. 2012. Penanganan Masalah Akibat Proses Menua. Modul. Depok : FIK UI.

Riskesdas. 2007.

Widyasari, D.F., \& Candrasari, A. $2010 . \quad$ Peningkatan pengetahuan tentang hipertensi pada lansia di Posyandu Lansia Dukuh Gantungan Desa Makamhaji Kartasura Sukoharjo. WARTA, Vol. 13. No. 1, Maret 2010: 28-36.

WHO. 2000. Diakses dari www.pdpersi.co.id pada tanggal 11 Juni 2013. 